\title{
Quality characteristics of kimchi with Artemisia annua extracts
}

\author{
Sang-Soo Lee ${ }^{*}$, Dong-Jin Kwon \\ Department of Food Processing and Distribution, Gangneung-Wonju National University, Gangneung 25457, Korea
}

\section{개똥쑥 추출물을 첨가한 김치의 품질특성}

\author{
이상수 * 권동진 \\ 강릉원주대학교 식품가공유통학과
}

\begin{abstract}
The quality characteristics of kimchi with Artemisia annua extracts (1 2\%; extracted with water or 70\% ethanol), including the $\mathbf{p H}$, acidity, reducing sugar content, total viable cell and lactic acid bacteria cell count, and sensory parameters, were investigated at 10 and $15^{\circ} \mathrm{C}$ for 20 days during aging. The $\mathrm{pH}$, acidity, reducing sugar content, and lactic acid bacteria count of kimchi with Artemisia annua extract rapidly increased upto the 4 -6th day, increasing slowly thereafter. The quality characteristics did not vary between kimchi with and without the extract. The optimal aging time for kimchi with the extract was 10 days at $10^{\circ} \mathrm{C}$. The results of the sensory evaluation showed that kimchi with $1 \%$ Artemisia annua extract was superior to kimchi with $2 \%$ Artemisia annua extract; in particular, the color and taste of the latter were found to be black and bitter, respectively.
\end{abstract}

Key words : Artemisia annua, kimchi, quality characteristics, sensory evaluation, lactic bacteria

\section{서 론}

김치는 채소류를 주원료로 하고 마늘, 생강 등의 각종 재료에서 유래된 맛 이외에 산, 탄산가스 등 발효 생산물의 조화를 지닌 맛을 지닌 우리나라 고유의 전통발효식품이 다. 김치는 배추와 무 등의 채소류와 마늘과 고춧가루 등 각종 향신료가 어우러진 전통식품이며(1) 유산균에 의한 젖산발효작용으로 독특한 맛과 영양을 지닌 채소발효식품 이다 $(2,3)$.

김치는 2001년 Codex 국제식품규격 채택(4) 이후 2006년 미국의 건강잡지인 "Health"에서 세계 5대 건강식품으로 선정되는 등 이제는 우리나라 전통식품에서 국제적인 식품 으로 관심이 높아지고 있다(5). 또한 급속한 경제발전과 핵가족화, 외식 및 단체급식의 증가 등으로 김치상품의 수

*Corresponding author. E-mail : neolao@naver.com

Phone : 82-33-650-3373, Fax : 82-33-648-2162

Received 11 September 2015; Revised 5 October 2015; Accepted 8 October 2015.

Copyright (c) The Korean Society of Food Preservation. All rights reserved.
요가 국내에서도 증가하고 있는 추세이다(6,7). 또한 각 지 역별로 채소류 이외에 김치의 품질 및 기능성을 향상시키기 위해 명태, 모과추출액, 감태, 전복과 다시마, 어성초, 인삼 등을 첨가하여 다양한 종류의 김치가 제조되고 있다(8).

최근에는 김치의 유산균에 대한 연구는 Bong 등(9)이 김치 유산균 Starter를 이용한 김치의 발효 특성 및 기능성 증진 효과, Ko 등(10)이 김치 종류에 따른 유산균의 생물학 적 및 기능적 특성에 관한 연구가 있으며, 김치의 기능성에 대한 연구로는 $\mathrm{Ku}$ 등(11)이 다시마를 첨가한 배추김치의 항산화 효과에 관한 연구가 있고, Choi(12)가 적갓김치 anthocyanins의 항산화 특성에 관한 연구가 있다.

개똥쑥 $(A$ annua)은 국화과에 속하는 일년생 초본으로 열대아시아를 원산지로 하여 전 세계적으로 분포되어 있으 며 우리나라에서는 전국 각지의 길가나 들판에 무리지어 야생하고 있다(13). 개똥쑥은 6 8월 사이 민가나 황무지 등에서 자라는 초롱꽃목 국화과의 쌍떡잎식물 한해살이풀 로 세계보건기구로부터 한약재로 지정돼 있다.

한방에서는 개똥쑥의 지상부를 청호라는 이름으로 해열 제, 지혈제, 피부병 치료제 및 살충제 등으로 사용하고 있으 며 그 외 항균, 항바이러스 및 항산화 작용 등이 알려져 
있다(14). 최근의 연구에 의하면 개똥쑥은 총 항산화력이 높은 약용식물 중의 하나로서 개똥쑥의 높은 항산화 활성은 시료 중에 함유된 페놀 화합물에 의한 것으로 보고 되어 있으며 $(15,16)$, chlorogenic acid, $\rho$-coumaric acid, coumarin, 6,7-dimethoxy-coumarin, luteolin-7-glucoside, rutin, quercetin, luteolin 및 kaempferol 등의 페놀 화합물이 분리, 동정 되었 다(17).

쑥에 관한 연구로는 Park 등(18)의 쑥과 솔잎의 항산화성 작용과 아질산염 소거작용에 관한 연구, Park 등(19)의 동충 하초, 쑥 및 솔잎 추출물의 항균작용에 관한 연구, Park 등(20)의 쑥 추출물의 기능과 쑥국수의 품질 특성을 조사한 연구 등 쑥의 기능성에 관한 연구가 주류를 이루고 있고, 개똥쑥에 관한 연구에는 Lee 등(21)의 한국산 개똥쑥의 재 배특성 및 수확시기에 따른 artemisinin의 함량변화를 조사 한 연구 등이 있으나 생리활성이 우수하고 최근 관심을 받고 있는 개똥쑥을 이용하여 식품을 제조하는 가공기술에 대한 연구는 거의 전무한 실정이다.

따라서 본 연구에서는 개똥쑥 추출물을 첨가하여 김치를 제조하고 제조된 개똥쑥 추출물 첨가 김치의 품질 특성 및 관능검사에 대해 조사하였다.

\section{재료 및 방법}

\section{실험재료}

본 실험의 김치 제조에 필요한 배추, 고춧가루 및 마늘 등의 원부재료는 강원도 인제에 소재한 마트에서 구입하여 사용하였다. 또한 개똥쑥은 강릉, 원주소재 재래시장에서 구입하였으며, 김치 제조에는 개똥쑥의 잎 부분을 사용하 였다.

\section{개똥쑥 추출물 제조}

개똥쑥의 물 추출물은 쑥 잎에 물을 가하여 $100^{\circ} \mathrm{C}$ 에서 4시간 환류 추출한 뒤 실온까지 냉각시킨 후 감압 여과한 여액을 회전식 감압 농축기(HS-2005S, Hashin S\&T Co., Ltd., Gangneung, Korea)로 $24^{\circ} \mathrm{Brix}$ 까지 농축하여 김치제조 에 사용하였다. 개똥쑥의 에탄올 추출물은 쑥 잎에 $70 \%$ 에탄올을 가하여 $80^{\circ} \mathrm{C}$ 에서 4 시간 환류 추출한 뒤 물 추출물 제조와 같은 방법으로 제조하였다.

\section{김치제조}

본 실험에 사용된 김치는 배추김치이며 여기에 개똥쑥 추출물을 첨가하였으며 제조비율은 Table 1에 나타내었다. 배추는 씻은 후 소금에 절임을 한 후 물빼기를 하였다. 배추 김치의 양념인 고춧가루, 무, 대파, 마늘, 생강, 설탕, 유산균 배양액, 부추, 양파, 참깨, 다시마 베이스, 찹쌀풀 및 육수를 넣어 버무려 양념부분을 준비하였다. 준비된 양념부분에 개똥쑥의 물 또는 $70 \%$ 에탄올 추출물을 1 또는 $2 \%$ 을 첨가
하였다. 소금에 절인 배추에 속재료 양념분으로 겹겹이 버 무린 후 적정숙성온도인 $10^{\circ} \mathrm{C}$ 와 이와 숙성온도의 차이를 대조하기 위하여 $10^{\circ} \mathrm{C}$ 보다 높은 $15^{\circ} \mathrm{C}$ 저장실에서 일정기간 발효 및 숙성을 하여 김치의 숙성 정도를 비교하였다.

Table 1. Composition of kimchi with Artemisia annua extracts

\begin{tabular}{|c|c|c|c|}
\hline \multirow[t]{2}{*}{ Ingredient } & \multirow[t]{2}{*}{ Control } & \multicolumn{2}{|c|}{$\begin{array}{l}\text { Artemisia annua extracts } \\
\text { (water or } 70 \% \text { ethanol) }\end{array}$} \\
\hline & & $1 \%$ & $2 \%$ \\
\hline Asian cabbage & 75.5 & 75.3 & 75.1 \\
\hline $\begin{array}{l}\text { Artemisia annua extracts } \\
\text { (water or } 70 \% \text { ethanol) }\end{array}$ & - & 0.2 & 0.4 \\
\hline Asian radish & 12.0 & 12.0 & 12.0 \\
\hline Green onion & 0.9 & 0.9 & 0.9 \\
\hline Red pepper powder & 2.8 & 2.8 & 2.8 \\
\hline Galic & 2.0 & 2.0 & 2.0 \\
\hline Ginger & 0.3 & 0.3 & 0.3 \\
\hline Salted sea foods & 1.4 & 1.4 & 1.4 \\
\hline Sugar & 0.6 & 0.6 & 0.6 \\
\hline Lactic acid bacteria culture broth & 0.1 & 0.1 & 0.1 \\
\hline Chives & 1.2 & 1.2 & 1.2 \\
\hline Onion & 0.8 & 0.8 & 0.8 \\
\hline Sesame & 0.1 & 0.1 & 0.1 \\
\hline Kelp extract & 0.5 & 0.5 & 0.5 \\
\hline Glutinous rice flour & 1.0 & 1.0 & 1.0 \\
\hline Gravy, Stocks & 0.8 & 0.8 & 0.8 \\
\hline Total & 100 & 100 & 100 \\
\hline
\end{tabular}

\section{$\mathrm{pH}$ 및 산도 측정}

저장 기간에 따른 $\mathrm{pH}$ 변화는 시료를 믹서기에서 분쇄한 후 여과지(Toyo No. 2)로 여과하여 $\mathrm{pH}$ meter(S220, Mettler Toledo, Uster, Switzerland)를 이용하여 3회 반복적으로 측 정하여 평균값으로 표시하였다. 시료의 적정 산도는 You 등(8)의 방법에 준하였다. 즉, 삼각플라스크에 시료 1 2 $\mathrm{g}$ 을 취한 후 증류수 $90 \mathrm{~mL}$ 정도를 넣고 1 시간동안 흔들어주 고, 여과지를 이용하여 여과한 후 $100 \mathrm{~mL}$ 로 정용한 다음 $10 \mathrm{~mL}$ 를 취하여 $0.1 \mathrm{~N} \mathrm{NaOH}$ 용액으로 적정하였다. 이때 지시약은 페놀프탈레인을 사용하였고 $\mathrm{pH}$ 가 8.4가 될 때까 지 적정하였으며 산도는 젖산으로 표시하였다.

\section{환원당 함량}

환원당은 Somogyi법(22)에 준하여 glucose로 환산하였 다. 시료를 제단백한 후 분석에 사용하였으며 시료액을 조 제하여 3,5-dinitrosalicylic acid를 첨가하여 발색시킨 후 spectrophotometer(8453 UV-Vis Spectrophotometer, G1103A, $\mathrm{HP}, \mathrm{Germany)}$ 의 $550 \mathrm{~nm}$ 에서 흡광도를 측정하여 환원당으 로 정량하였다. 같은 방법으로 glucose의 검량곡선(calibration 
curve)을 작성하여 환원당량을 구하였다.

\section{생균수 및 젖산균}

개똥쑥이 첨가된 배추김치를 취하여 믹서기에서 마쇄한 후 $0.85 \%$ saline 용액으로 단계 희석하여 실험을 실시하였 다. 생균수는 plate count agar(PCA) 배지에 단계 희석한 시료를 접종하고(23) $30^{\circ} \mathrm{C}$ 에서 48 시간 배양한 후 계수하고, 젖산균수는 $\mathrm{MRS}$ 배지에 접종하여(24) $30^{\circ} \mathrm{C}$ 에서 48 96시 간 배양한 후 계수하였다. 계수한 총 세균과 젖산균 집락 수는 colony forming unit(CFU/g)로 표시하였다.

\section{관능검사}

개똥쑥 추출물이 첨가된 배추김치에 대한 관능검사는 잘 훈련된 관능검사원을 대상으로 기호도 특성을 평가하였 다. 관능적 기호도는 9점 척도법(1점 대단히 싫다. 9점 대단 히 좋다)을 사용하여 맛(taste), 향(flavor), 색(color), 조직감 (texture) 및 전체적인 기호도(overall acceptability) 등 총 5가 지 항목에 대해 실시하였다. 모든 실험의 결과는 평균치와 표준편차로 나타내었으며 통계처리는 SPSS(12, SPSS Inc., Chicago, IL, USA)를 이용하였고 Duncan's multiple range test를 시행하여 $\mathrm{p}<0.05$ 수준에서 유의성 검정을 하였다(25).

\section{결과 및 고찰}

\section{$\mathrm{pH}$ 및 산도 측정}

김치의 숙성 과정에서 큰 성분변화는 $\mathrm{pH}$ 와 산도의 변화 이다. 이는 젖산발효에 의해 생선되는 유기산 함량의 증가 로 $\mathrm{pH}$ 는 감소하고 산도는 증가하게 되어 김치 숙성정도를 알 수 있는 지표로 사용하고 있다(8). 개똥쑥 추출물 첨가 김치의 온도 및 저장기간에 따른 $\mathrm{pH}$ 측정 결과는 Fig. 1 과

A

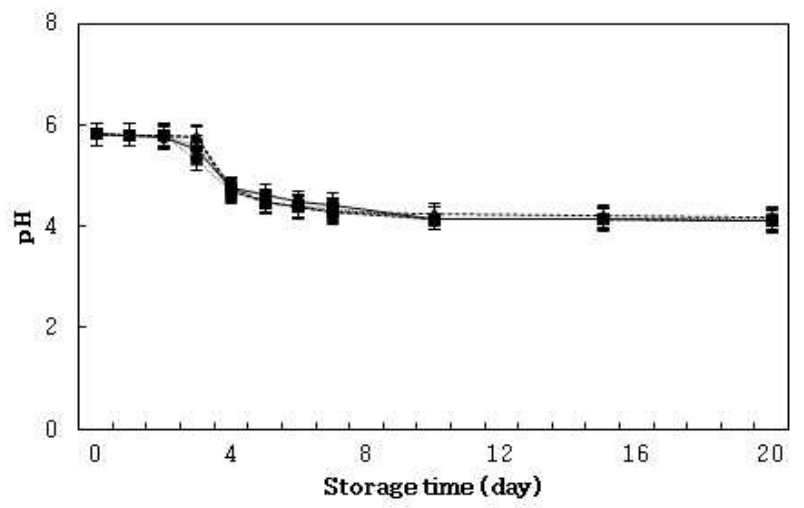

같다. 개똥쑥 추출물을 첨가하지 않은 대조구 김치와 개똥 쑥의 물 또는 $70 \%$ 에탄올 추출물 1 또는 $2 \%$ 첨가한 김치를 $10^{\circ} \mathrm{C}$ 와 $15^{\circ} \mathrm{C}$ 에 숙성하면서 $\mathrm{pH}$ 를 측정한 결과, 모든 시료가 숙성 2 3일까지 큰 변화없이 일정한 수준을 유지하다가 이후 $15^{\circ} \mathrm{C}$ 저장구는 4 일, $10^{\circ} \mathrm{C}$ 저장구는 6 일까지 급격히 감소하고 이후 숙성 20 일까지 완만히 감소하는 것을 볼 수 있었다.

$10^{\circ} \mathrm{C}$ 숙성 처리구의 경우 대조구 김치의 $\mathrm{pH}$ 는 숙성 초기 에는 5.81을 보이고 숙성 4 일부터 급격히 낮아진 후 숙성 6 일부터 완만히 감소하여 숙성 20 일째에 4.11 을 나타내었 다. 개똥쑥의 물 추출물 $1 \%$ 또는 $2 \%$ 을 첨가한 김치는 대조 구 김치와 비슷하게 경향을 보였고 20 일째에 4.13 을 보였 다. 개똥쑥의 $70 \%$ 에탄올 추출물 $1 \%$ 또는 $2 \%$ 을 각각 첨가 한 김치 역시 숙성 초기에 5.81을 보이다가 숙성 20 일째에 는 각각 4.17 및 4.11 을 나타내었다.

$15^{\circ} \mathrm{C}$ 숙성 처리구의 김치는 $10^{\circ} \mathrm{C}$ 숙성 처리구 김치들보다 1 일 빠르게 $\mathrm{pH}$ 가 급격히 낮아진 후 유사한 감소 경향을 보였다. 숙성 20 일째에 대조구 김치는 3.89 , 물 추출물 $1 \%$ 을 첨가한 김치는 $3.93,2 \%$ 을 첨가한 김치는 3.94 을 보였으며, 개똥쑥의 $70 \%$ 에탄올 추출물 $1 \%$ 을 첨가한 김치는 4.08 , $2 \%$ 을 첨가한 김치는 3.99 로 나타났다.

이런 결과는 Chang 등(26)이 시판 김치를 $10^{\circ} \mathrm{C}$ 에 보관하 면서 $\mathrm{pH}$ 를 조사한 결과 숙성 2 일까지 큰 변화없이 유지하다 숙성 7일까지 급격히 감소하였다는 것과는 유사한 결과였다.

이런 결과로부터 숙성 20 일까지 숙성하여도 모든 처리 구, 즉 개똥쑥의 물 또는 $70 \%$ 에탄올 추출물을 첨가한 김치 는 전통식품표준규격(27)에서 정한 $\mathrm{pH} 3.8$ 이상을 만족하 고 있는 것으로 나타나 적당한 산도를 지니고 있음을 알 수 있었다.

개똥쑥의 물 또는 $70 \%$ 에탄올 추출물을 1 또는 $2 \%$ 첨가 한 김치를 10 또는 $15^{\circ} \mathrm{C}$ 저장구에 20 일간 숙성시키면서

Fig. 1. Changes in $\mathrm{pH}$ of kimchi with Artemisia annua extract during storage at 10 and $15^{\circ} \mathrm{C}$.

A, kimchi stored at $10^{\circ} \mathrm{C}$; B, kimchi stored at $15^{\circ} \mathrm{C}$. control (kimchi without Artemisia annua); $\mathbf{\square}$, kimchi added with $1 \%$ Artemisia annua concentrate extracted by water; $\square$, kimchi added with $2 \%$ Artemisia annua concentrate extracted by water, $\boldsymbol{\Delta}$, kimchi added with $1 \%$ Artemisia annua concentrate extracted by ethanol; $\Delta$, kimchi added with $2 \%$ Artemisia annua concentrate extracted by ethanol. 
산도 변화를 측정한 결과는 Fig. 2와 같다.

Fig. 2에서 보는 바와 같이 숙성 온도가 높을수록 산의 생성이 많은 것을 볼 수 있었다. 즉 $10^{\circ} \mathrm{C}$ 숙성 처리구의 경우 숙성 1 일까지 산의 생성을 볼 수 없었으나, 숙성 1 일이 후 2 일까지 급격히 증가하고 숙성 3 일 이후 완만히 증가하 고 있는 반면 $15^{\circ} \mathrm{C}$ 숙성 처리구의 경우 숙성 초기부터 숙성 9일까지 산의 생성이 급격히 증가하고 이후 완만히 증가하 고 있는 것을 볼 수 있었다.

전통식품규격(27)에 나와 있는 산도의 기준인 $1.0 \%$ 이하 를 대부분 만족하고 있으나 $15^{\circ} \mathrm{C}$ 숙성 처리구에서 대조구가 숙성 20 일째에 $1.06 \%$ 를 나타내고 있어 전통식품규격의 $1.0 \%$ 보다 약간 많은 산을 생성하고 있어 김치의 적정 숙성 온도는 $10^{\circ} \mathrm{C}$ 임을 알 수 있었다. 또한 개똥쑥의 추출물을 첨가하지 않은 대조구는 숙성 1 일 이후부터 산의 생성이 급격히 증가하고 있는데 반해 개똥쑥의 물 또는 $70 \%$ 에탄 올 추출물을 첨가한 김치는 산의 생성이 대조구에 비해 숙성 중기, 즉 숙성 8 일 이후부터 산의 생성이 적어 개똥쑥 추출물이 어느 정도 산의 생성을 억제하고 있는 것으로 나타났다.

\section{환원당}

환원당은 김치의 단맛과 신맛 생성에 매우 큰 영향을 미칠 뿐만 아니라 환원당을 이용하여 유산균에 의해 lactic acid 등을 포함하는 유기산 생성에 밀접한 관계를 갖고 있으 며, $\mathrm{pH}$ 와 산도의 변화에 영향을 미치기 때문에 환원당 함량 의 변화를 관찰하였다.

개똥쑥의 물 또는 $70 \%$ 에탄올 추출물을 1 또는 $2 \%$ 첨가 한 김치를 $10,15^{\circ} \mathrm{C}$ 저장구에 20 일 동안 숙성하면서 환원당 의 변화를 측정한 결과는 Fig. 3 과 같다.

Fig. 3에서 보는 바와 같이 숙성온도가 높을수록 환원당 의 소비가 많은 것으로 나타났다. $10^{\circ} \mathrm{C}$ 숙성 처리구의 경우

A

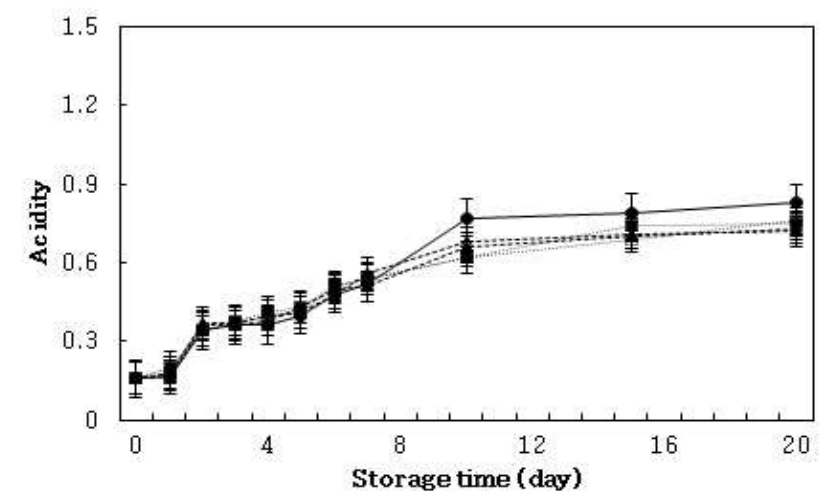

숙성 4 일까지 환원당의 감소가 급격히 진행되고 이후 완만 히 감소하는 경향을 보이고 있는 반면 $15^{\circ} \mathrm{C}$ 숙성 처리구에 서는 숙성 9 일까지 환원당이 급격히 감소하고 이후 숙성 20 일까지 완만히 감소하고 있는 것을 볼 수 있었다. 이런 환원당의 감소경향은 Shin 등(28)이 김치를 $4{ }^{\circ} \mathrm{C}$ 숙성 처리 구에 보관하면서 7 일 간격으로 시료를 채취하여 환원당의 변화를 조사한 결과 초기부터 환원당이 감소하는 경향을 보이고 있는 결과와 유사하였다. 이와 같이 환원당이 감소 하는 이유로는 발효과정 중에 미생물 수의 증가로 환원당을 이용하여 김치의 풍미물질인 lactic acid, acetic acid, alcohol 등의 물질을 생성하거나 전환시키는데 이용되기 때문(29) 인 것으로 사료된다. 또한 개똥쑥의 첨가가 환원당의 미치 는 영향은 크지 않은 것으로 나타났다.

\section{생균수}

개똥쑥의 물 또는 $70 \%$ 에탄올 추출물을 1 또는 $2 \%$ 첨가 한 김치를 $10,15^{\circ} \mathrm{C}$ 숙성 처리구에서의 생균수 변화를 측정 한 결과는 Fig. 4와 같다.

Fig. 4에서 보는 바와 같이 숙성 초기의 균수에서 급격히 증가하고 이후 완만히 증가하는 것을 볼 수 있었다. 즉 $10^{\circ} \mathrm{C}$ 숙성 처리구의 경우 숙성 초기 균수가 $1.5 \times 10^{7} \mathrm{CFU} / \mathrm{g}$ 이였 고, 숙성 5 일까지 급격히 증가하고 이후 완만히 증가하여 숙성 20 일째에는 $9.1 \times 10^{8} \mathrm{CFU} / \mathrm{g}$ 을 나타냈다. $15^{\circ} \mathrm{C}$ 숙성 처 리구는 $10^{\circ} \mathrm{C}$ 보다 일찍 숙성되어 균수가 2 일까지 급격히 증가하고 이후 완만히 증가하여 숙성 20 일째에는 $3.7 \times 10^{8}$ $\mathrm{CFU} / \mathrm{g}$ 으로 숙성 온도가 높을수록 균의 증식속도가 빠르다 는 결과를 나타냈다. 개똥쑥의 물 추출물 $1 \%$ 또는 $2 \%, 70 \%$ 에탄올 추출물 $1 \%$ 또는 $2 \%$ 첨가하여 $10^{\circ} \mathrm{C}$ 숙성 처리 김치 의 생균수는 숙성 20 일째에 각각 $4.3 \times 10^{8} \mathrm{CFU} / \mathrm{g}, 2.3 \times 10^{8}$ $\mathrm{CFU} / \mathrm{g}, 2.3 \times 10^{8} \mathrm{CFU} / \mathrm{g}, 2.3 \times 10^{8} \mathrm{CFU} / \mathrm{g}$ 으로 나타났다. $15^{\circ} \mathrm{C}$ 숙성 처리구의 생균수는 숙성 20 일째에 각각 $6.3 \times 10^{8}$

B

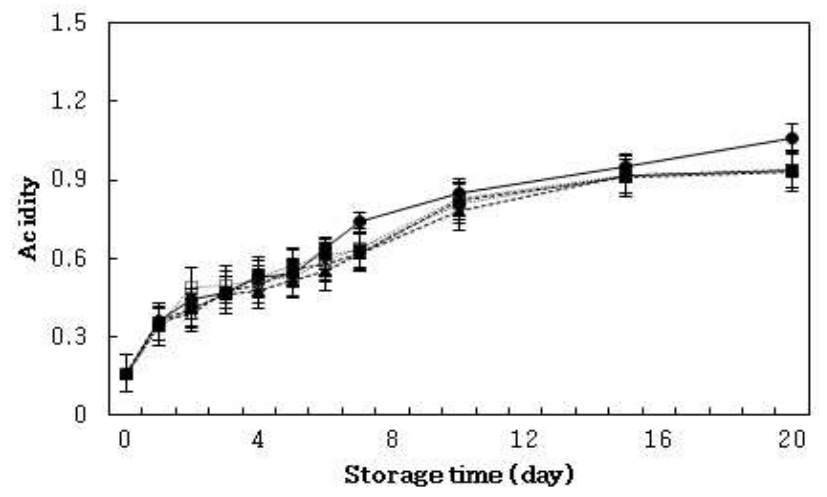

Fig. 2. Changes in acidity of kimchi with Artemisia annua extract during storage at 10 and $15^{\circ} \mathrm{C}$.

A, kimchi stored at $10^{\circ} \mathrm{C}$; B, kimchi stored at $15^{\circ} \mathrm{C}$. control (kimchi without Artemisia annua); $\mathbf{\square}$, kimchi added with $1 \%$ Artemisia annua concentrate extracted by water; $\square$, kimchi added with $2 \%$ Artemisia annua concentrate extracted by water; $\boldsymbol{\Lambda}$, kimchi added with $1 \%$ Artemisia annua concentrate extracted by ethanol; $\triangle$, kimchi added with 2\% Artemisia annua concentrate extracted by ethanol. 
A

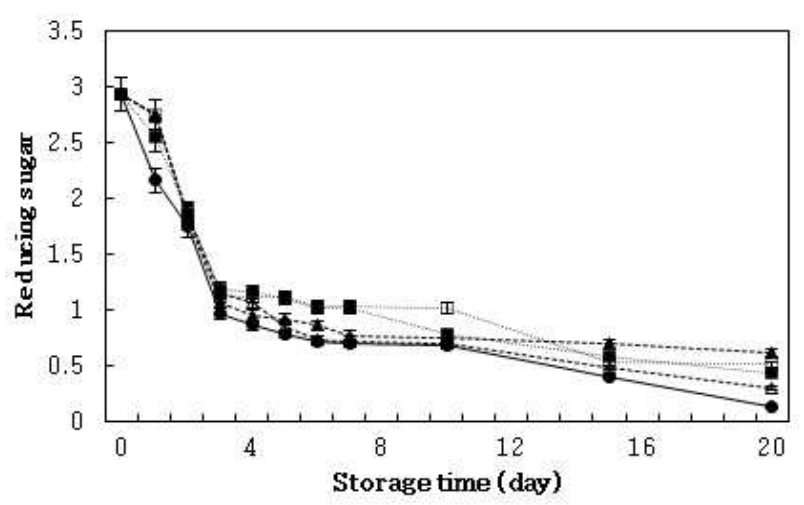

B

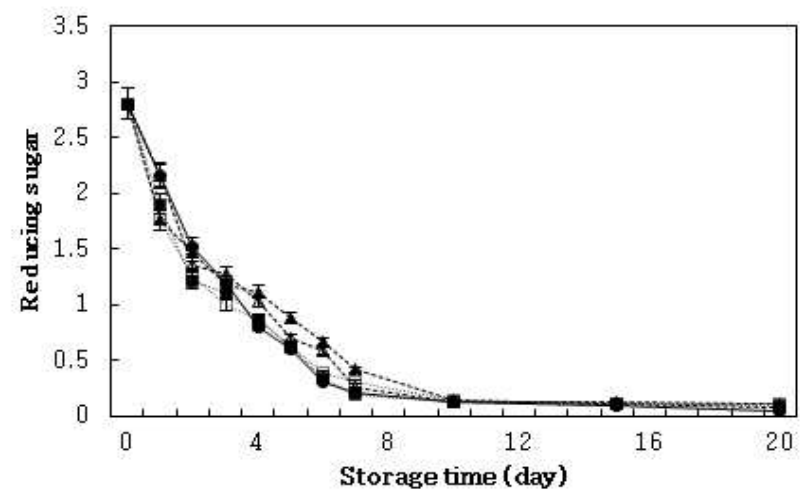

Fig. 3. Changes in reducing sugar content of kimchi with Artemisia annua extract during storage at 10 and $15^{\circ} \mathrm{C}$.

A, kimchi stored at $10^{\circ} \mathrm{C} ; \mathrm{B}$, kimchi stored at $15^{\circ} \mathrm{C}$. $\square$, kimchi added with $2 \%$ Artemisia annua concentrate extracted by water; $\boldsymbol{\Delta}$, kimchi added with $1 \%$ Artemisia annua concentrate extracted by ethanol; $\triangle$, kimchi added with $2 \%$ Artemisia annua concentrate extracted by ethanol.

A

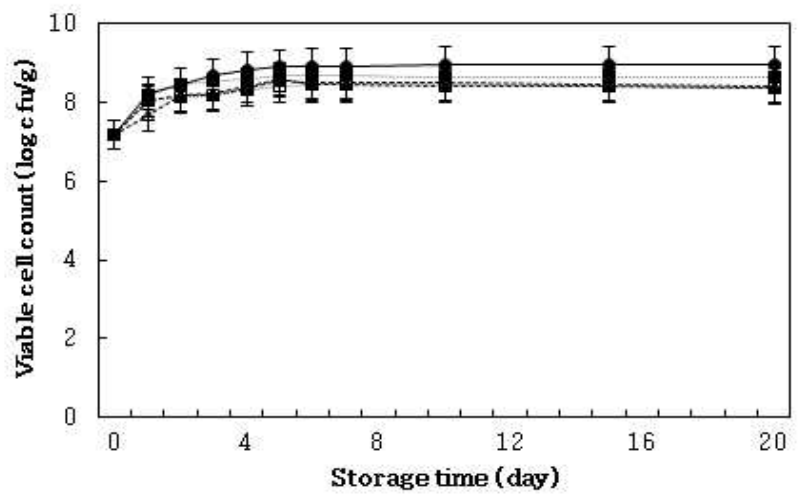

B

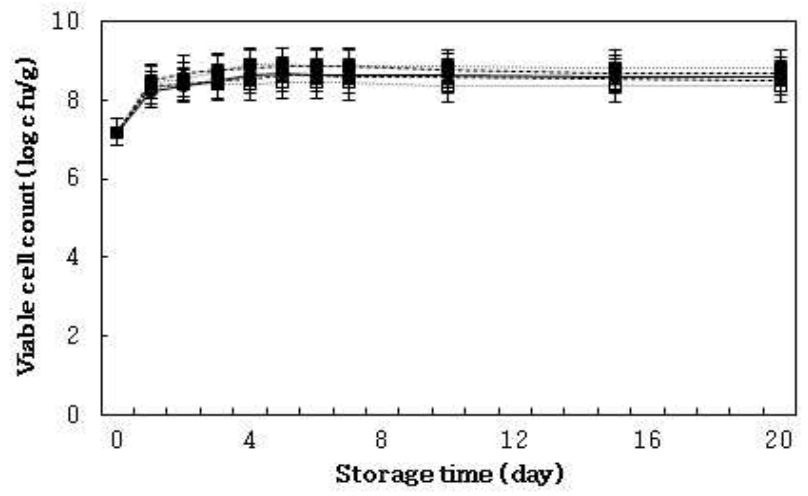

Fig. 4. Changes in viable cell count of kimchi with Artemisia annua extract during storage at 10 and $15^{\circ} \mathrm{C}$.

A, kimchi stored at $10^{\circ} \mathrm{C}$; B, kimchi stored at $15^{\circ} \mathrm{C}$. control (kimchi without Artemisia annua); $\mathbf{\square}$, kimchi added with $1 \%$ Artemisia annua concentrate extracted by water; $\square$, kimchi added with $2 \%$ Artemisia annua concentrate extracted by water; $\boldsymbol{\Lambda}$, kimchi added with $1 \%$ Artemisia annua concentrate extracted by ethanol; $\triangle$, kimchi added with $2 \%$ Artemisia annua concentrate extracted by ethanol.

$\mathrm{CFU} / \mathrm{g}, 2.2 \times 10^{8} \mathrm{CFU} / \mathrm{g}, 4.7 \times 10^{8} \mathrm{CFU} / \mathrm{g}, 3.2 \times 10^{8} \mathrm{CFU} / \mathrm{g}$ 으로 나타났다. 개똥쑥 추출물의 첨가여부와 관계없이 모든 처 리구가 비슷한 증가 경향을 보여 개똥쑥 추출물이 세균의 생육억제 효과는 없는 것으로 나타났으며 이런 생균수의 변화 경향은 Chang 등(26)이 김치를 $10^{\circ} \mathrm{C}$ 에 10 일간 숙성하 면서 생균수를 살펴본 결과 숙성 2 4일 사이에 생균수의 증가가 가장 왕성하고 그 후 6일 8일경에 최고 균수에 도달 한다는 결과와 유사하였다.

이상의 결과로부터 $10,15^{\circ} \mathrm{C}$ 숙성 처리구의 경우 숙성 온도가 높아질수록 생균수의 증가속도는 빨랐으나 개똥쑥 추출물의 첨가로 인해 생균수를 억제하는 경향은 보이지 않았다.

\section{젖산균수}

개똥쑥의 물 또는 $70 \%$ 에탄올 추출물을 1 또는 $2 \%$ 첨가 한 김치를 $10,15^{\circ} \mathrm{C}$ 항온기에 20 일 동안 숙성하면서 젖산균 수의 변화를 측정한 결과는 Fig. 5와 같다.

Fig. 5에서 보는 바와 같이 젖산균수는 숙성 초기부터 급격히 증가하는 경향을 볼 수 있다. 즉 $10^{\circ} \mathrm{C}$ 숙성 처리구의 경우 숙성 초기부터 균수가 $4.5 \times 10^{6} \mathrm{CFU} / \mathrm{g}$ 로 숙성 6 일까지 급격히 증가하고 이후 숙성 20 일에 $8.9 \times 10^{8} \mathrm{CFU} / \mathrm{g}$ 까지 완 만한 균수의 변화를 볼 수 있다. 또한 $15^{\circ} \mathrm{C}$ 숙성 처리구의 경우 숙성 1 일까지 급격히 증가하고 이후 완만히 증가하고 있어 숙성 온도가 높을수록 균의 증식속도가 빨랐다. 이와 같이 젖산균수의 변화 경향은 Chang 등(26)이 김치를 $10^{\circ} \mathrm{C}$ 에 10 일간 숙성하면서 젖산균수를 살펴본 결과 숙성 6 일까 
A

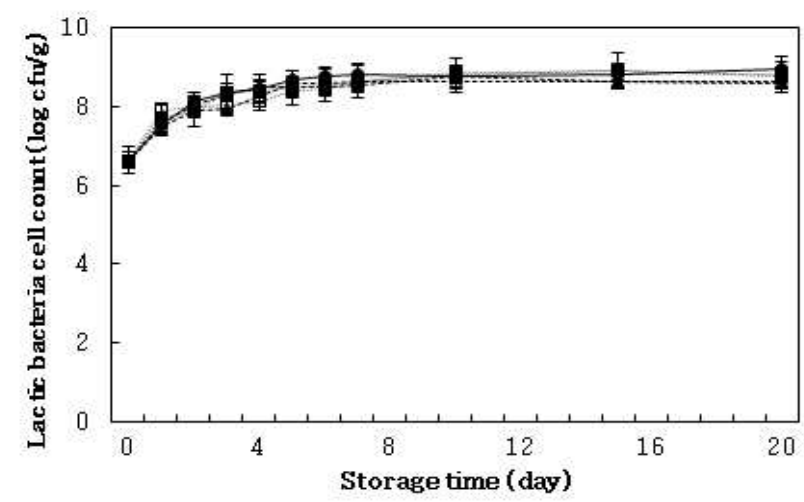

B

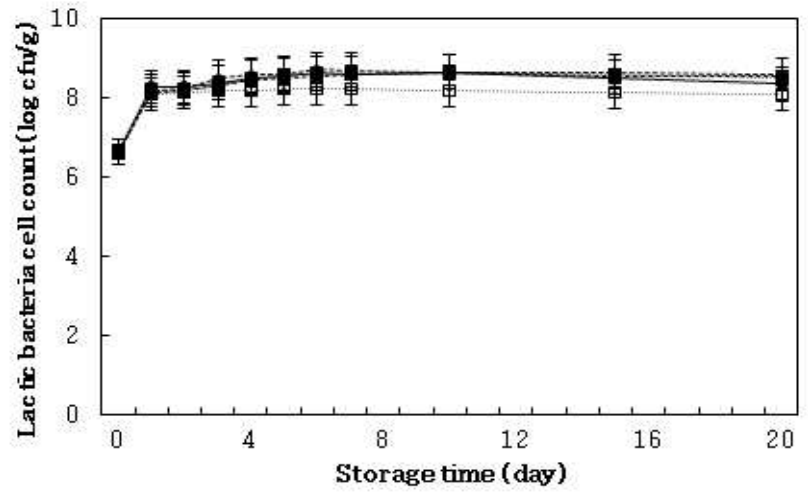

Fig. 5. Changes in lactic acid bacteria count of kimchi added with Artemisia annua extract during storage at 10 and $15^{\circ} \mathrm{C}$.

A, kimchi stored at $10^{\circ} \mathrm{C} ; \mathrm{B}$, kimchi stored at $15^{\circ} \mathrm{C}$. $\mathrm{O}$, control (kimchi without Artemisia annua); $\mathbf{\square}$, kimchi added with $1 \%$ Artemisia annua concentrate extracted by water; $\square$, kimchi added with $2 \%$ Artemisia annua concentrate extracted by water; $\boldsymbol{\Delta}$, kimchi added with $1 \%$ Artemisia annua concentrate extracted by ethanol; $\triangle$, kimchi added with $2 \%$ Artemisia annua concentrate extracted by ethanol.

지 급격히 증가하고 이후 완만히 증가하였다는 결과와 유사 하였으며 균수 또한 비슷하였다. $10,15^{\circ} \mathrm{C}$ 숙성 처리구의 경우 숙성 온도가 높아질수록 젖산균의 증가속도가 빨랐으 나 개똥쑥의 첨가로 인해 젖산균수의 생육 억제 또는 촉진 하는 경향은 보이지 않았다.

이상의 결과들로부터 개똥쑥을 물 또는 $70 \%$ 에탄올 추출 물을 1 또는 $2 \%$ 첨가한 김치의 $\mathrm{pH}$, 산도, 환원당, 세균수 및 젖산균수의 변화를 고려할 때 김치의 적정 숙성기간은 $10^{\circ} \mathrm{C}$ 에서 10 일간이 적당하였다. 또한 개똥쑥이 김치 제조 에 미치는 영향은 크지 않은 것으로 나타나 품질면에서는 개똥쑥을 첨가하지 않은 김치와 유의적인 차이를 보이고 있지 않았다.

\section{관능검사}

개똥쑥 추출물을 첨가한 김치의 품질 특성을 조사하기 위해 개똥쑥의 추출 추출물을 첨가하여 제조한 김치를 $10^{\circ} \mathrm{C}$ 에 10 일간 숙성한 후 관능검사를 실시한 결과는 Table 2 과 같다.

Table 2에서 보는 바와 같이 개똥쑥 추출물을 첨가한 김치의 관능검사 결과 맛의 경우 $5 \%$ 수준에서 시료 간에 유의성이 있는 것으로 나타났다. 개똥쑥 추출물을 첨가하 지 않은 대조구는 8.00 점을 얻고 있으며 개똥쑥 물 추출물 $1 \%$ 을 첨가한 김치와 개똥쑥 에탄올 추출물 $1 \%$ 을 첨가한 김치가 각각 $7.30,7.70$ 점을 얻고 있어 대조구와 큰 차이를 보이고 있지 않았다. 그러나 개똥쑥 물 추출물 $2 \%$ 을 첨가한 김치는 6.00 점, 개똥쑥 에탄올 추출물 $2 \%$ 을 첨가한 김치는 3.10 점을 얻고 있어 개똥쑥 첨가량이 많으면 맛에 대한 관능 적 기호도가 크게 떨어지는 것으로 나타났다. 이런 결과로 부터 개똥쑥의 물 또는 에탄올 추출물의 첨가량은 $1 \%$ 이 적절한 것으로 나타났다.
Table 2. Sensory evaluation of kimchi with Artemisia annua extract

\begin{tabular}{cccccc}
\hline Treatment & Control & $\mathrm{A}^{1 \mathrm{l}}$ & $\mathrm{B}$ & $\mathrm{C}$ & $\mathrm{D}$ \\
\hline Taste & $8.00 \pm 1.88^{\mathrm{a} 22}$ & $7.30 \pm 1.25^{\mathrm{a}}$ & $6.00 \pm 1.05^{\mathrm{b}}$ & $7.70 \pm 1.05^{\mathrm{a}}$ & $3.10 \pm 1.44^{\mathrm{c}}$ \\
Flavor & $7.50 \pm 1.35^{\mathrm{a}}$ & $7.50 \pm 0.70^{\mathrm{a}}$ & $6.50 \pm 0.97^{\mathrm{ab}}$ & $7.50 \pm 0.94^{\mathrm{a}}$ & $6.00 \pm 1.56^{\mathrm{b}}$ \\
Color & $8.09 \pm 1.38^{\mathrm{a}}$ & $7.80 \pm 1.22^{\mathrm{a}}$ & $6.60 \pm 0.96^{\mathrm{b}}$ & $7.40 \pm 1.13^{\mathrm{a}}$ & $5.88 \pm 1.53^{\mathrm{c}}$ \\
Texture & $7.80 \pm 1.22^{\mathrm{a}}$ & $7.60 \pm 1.74^{\mathrm{a}}$ & $7.60 \pm 0.69^{\mathrm{a}}$ & $7.80 \pm 0.91^{\mathrm{a}}$ & $7.80 \pm 1.39^{\mathrm{a}}$ \\
$\begin{array}{c}\text { Overall } \\
\text { acceptability }\end{array}$ & $8.10 \pm 1.79^{\mathrm{a}}$ & $7.10 \pm 1.19^{\mathrm{a}}$ & $6.40 \pm 1.07^{\mathrm{b}}$ & $7.10 \pm 1.28^{\mathrm{a}}$ & $6.30 \pm 1.88^{\mathrm{b}}$ \\
\hline
\end{tabular}

${ }^{11}$ A, kimchi added with $1 \%$ Artemisia annua concentrate extracted by water; B, kimchi added with $2 \%$ Artemisia annua concentrate extracted by water; $\mathrm{C}$, kimchi added with $1 \%$ Artemisia annua concentrate extracted by ethanol; D, kimchi added with $2 \%$ Artemisia annua concentrate extracted by ethanol.

${ }^{2)}$ Each value represents the mean $\pm \mathrm{SD}$ of 10 observations using hedonic scale of 1 (dislike very much) to 9 (like very much). Different superscripts in the same significantly different by Duncan's multiple range test $(\mathrm{p}<0.05)$.

향의 경우 개똥쑥 추출물 첨가량이 많을수록 낮은 점수 를 얻고 있으며 $5 \%$ 수준에서 유의성이 인정되어 시료 간에 차이가 있는 것으로 나타났다. 개똥쑥 추출물을 첨가하지 않은 대조구와 개똥쑥 물 또는 에탄올 추출 추출물을 $1 \%$ 첨가한 김치는 7점 이상을 얻고 있으나 개똥쑥 물 또는 에탄올 추출 추출물을 $2 \%$ 첨가한 김치는 각각 $6.50,6.00$ 점 을 얻고 있어 향도 개똥쑥 추출물을 $1 \%$ 첨가하는 것이 바람직한 것으로 나타났다.

색의 경우 $5 \%$ 수준에서 유의성이 인정되어 시료 간에 차이가 있는 것으로 나타났다. 또한 개똥쑥 추출물이 많이 첨가될수록 김치의 색이 검은 색을 띠어 관능적 기호도가 낮은 것으로 나타났다. 색에 있어서도 개똥쑥 물 또는 에탄 올 추출물 $1 \%$ 을 첨가한 것이 7.80 점, 7.40 점을 얻고 있는 반면 개똥쑥 추출물 $2 \%$ 을 첨가한 김치는 각각 $6.60,5.88$ 점 을 얻고 있어 개똥쑥이 김치의 색을 검게 하여 관능적 기호 
도가 떨어지는 것으로 나타났다.

조직감의 경우 $5 \%$ 수준에서 유의성이 인정되지 않아 시료 간에 차이가 없는 것으로 나타났으며 전체적으로 대조 구와 비슷한 7.60점 이상을 얻고 있었다.

전체적인 기호도의 경우 $5 \%$ 수준에서 유의성이 인정되 어 시료 간에 차이가 있는 것으로 나타났다. 즉 개똥쑥 추출 물이 $2 \%$ 첨가된 김치는 대조구와 개똥쑥 물 또는 에탄올 추출물이 $1 \%$ 첨가된 김치보다 낮은 점수를 얻고 있어 개똥 쑥 추출물의 첨가량은 $1 \%$ 이 적당한 것으로 사료된다.

이상의 관능검사를 종합해 볼 때 개똥쑥 물 또는 $70 \%$ 에탄올 추출물을 김치 제조할 때 $1 \%$ 을 첨가하는 것이 적절 한 것이 관능적 기호도가 우수한 것으로 으로 나타났다.

\section{요 약}

본 연구에서는 항암 등의 기능성이 우수한 것으로 알려 진 개똥쑥 추출물을 첨가하여 김치를 제조하여 김치 품질 특성 변화를 살펴보았다. 개똥쑥의 물 또는 $70 \%$ 에탄올로 추출물 1 또는 $2 \%$ 첨가하여 김치를 제조하고 $10,15^{\circ} \mathrm{C}$ 에서 20 일간 숙성하면서 $\mathrm{pH}$, 산도, 환원당, 생균수 및 젖산균수 의 변화 및 관능조사를 하였다. 개똥쑥의 첨가여부와는 관 계없이 $\mathrm{pH}$, 산도 환원당, 생균수 및 젖산균수는 저장 4 6일 까지 증가하고 이후 완만히 증가하는 경향을 보여 개똥쑥 추출물이 김치 품질에 미치는 영향은 크지 않은 것으로 나타났으며 개똥쑥 추출물 첨가 김치의 적정 숙성온도 및 기간은 $10^{\circ} \mathrm{C}$ 에서 10 일간이었다. 관능검사의 경우 맛, 향 등의 기호도에서 전반적으로 개똥쑥 물 또는 에탄올 추출물 $1 \%$ 를 첨가하여 제조하는 것이 좋았으나 개똥쑥 물 또는 에탄올 추출물 $2 \%$ 를 첨가한 김치는 쓴 맛과 검은 색 등으로 인해 기호도가 떨어진 것으로 나타났다. 따라서 개똥쑥 물 또는 에탄올 추출물은 김치 제조에 $1 \%$ 를 김치 제조에 첨가 하는 것이 적당한 것으로 사료된다.

\section{감사의 글}

본 연구는 중소기업청에서 지원하는 2013년도 산학연협 력 기술개발사업(No. C0123282)의 연구수행으로 인한 결 과물임을 밝힙니다.

\section{References}

1. Chang JY, Choi YR, Chang HC (2011) Change in the microbial profiles of commercial kimchi during fermentation. Korean J Food Preserv, 18, 786-794
2. Lee CH (1986) Kimchi : Korean fermented vegetable foods. Korean J Dietary Culture, 1, 395-402

3. Ku KH, Sunwoo JY, Park WS (2005) Effects of ingredients on the its quality characteristics during kimchi fermentation. J Korean Soc Food Sci Nutr, 34, 267-276

4. Codex (2001) Alimentarius Commission. Codex standard for kimchi. Codex Stan, 223

5. Jeon CG (2009) Marketing analysis of imported kimchi and challenges for the domestic kimchi industry. Korean J Food Marketing Economics, 26, 79-101

6. Kim OS, Joo NM (2007) A study on purchasing current status and promotion factors for commercial kimchi of women in seoul area. Korean J Food Culture, 22, 167-175

7. You JH, Shin MJ, Choi SK (2008) Importance and satisfaction with selection attributes when purchasing kimchi. J East Asian Soc Dietary Life, 18, 624-632

8. You BR, Kim HJ (2013) Quality characteristics of kimchi added with Allium hookeri root. J Korean Soc Food Sci Nutr, 42, 1649-1655

9. Bong YJ, Jeong JK, Park KY (2013) Fermentation properties and increased health functionality of kimchi lactic acid bacteria starters. J Korean Soc Food Sci Nutr, 42, 1717-1726

10. Ko KH, Liu W, Lee HH, Yin J, Kim IC (2013) Biological and functional characteristics of lactic acid bacteria in different kimchi. J Korean Soc Food Sci Nutr, 42, 89-95

11. Ku HS, Noh JS, Kim HJ, Cheigh HS, Song YO (2007) Antioxidant effects of sea tangle added Korean cabbage kimchi in vitro and in vivo. J Korean Soc Food Sci Nutr, $36,1497-1502$

12. Cheigh HS (2003) Antioxidative activities of anthocyanins in red mustard leaf kimchi. J Korean Soc Food Sci Nutr, 32, 937-941

13. Ryu JH, Lee SJ, Kim MJ, Shin JH, Kang SK, Cho KM, Sung NJ (2011) Antioxidant and anticancer activities of Artemisia annua L. and determination of functional compounds. J Korean Soc Food Sci Nutr, 40, 509-516

14. Romero MR, Serrano MA, Efferth T, Alvarez M, Marin JJ (2006) Antivaral effect of artemisinin from Artemisia annua against a model member of the Flaviviridae family, the bovine viral diaahoea virus (BVDV). Planta Med, 72, 1169-1174

15. Brisibe EA, Umoren UE, Brisibe F, Nagalhaes PM, Ferreira JFS, Luthria D, Wu X, Prior RL (2009) Nutritional characterisation and antioxidant capacity of different tissues of Artemisia annua L. Food Chem, 115, 1240-1246 
16. Zheng W, Wang SY (2001) Antioxidant activity and phenolic compounds in selected herbs. J Agric Food Chem, 49, 5165-5170

17. Cai Y, Luo Q, Sun M (2004) Antioxidant activity and phenolic compounds of 112 traditional chinese medicinal plants associated with anticancer. Life Sci, 74, 2157-2184

18. Park CS, Kwon CJ, Choi MA, Park GS, Choi KH (2002) Antioxidative and nitrite scavenging activiess of mugwort and pine needle extracts. Korean J Food Preserv, 9, 248-252

19. Park CS, Kwon CJ, Choi MA, Park GS, Choi KH (2002) Antibacterial activities of Cordyceps spp., mugwort and pine needle extracts. Korean J Food Preserv, 9, 102-108

20. Park CS, Kim ML (2006) Functional properties of mugwort extracts and quality characteristics of noodles added mugwort powder. Korean J Food Preserv, 13, 161-167

21. Lee JH, Lee SH, Park CG, Park CB, Kim OT, Choi AJ, Kim YJ, Cha SW (2013) Cultivation characteristics and variation of artemisinin contents by harvest time. Korean J Med Crop Sci, 21, 433-438

22. Somogyi M (1927) Notes on sugar determination. J
Biological Chem, 195, 19-23

23. PCA (1984) Difco Manual. 19th ed, Difco laboratories. Michigan, p 679

24. MRS broth (1984) Difco Manual. 19th ed, Difco laboratories. Michigan, p 493

25. SAS (1998) SAS User's guide statistics, 3rd ed, SAS Institute Statistical Analysis System institute, Cary, NC, USA

26. Chang JY, Choi YR, Chang CC (2011) Change in the microbial profiles of commercial kimchi during fermentation. Korean J Food Preserv, 15, 786-794

27. Korean traditional food standard (2013) National Agricultural Products Quality Management Service, Korea, p 126-132

28. Shin JH, Kim RJ, Kang MJ, Kim GM (2012) Quality and fermentation characteristics of garlic-added kimchi. Korean J Food Preserv, 19, 539-546

29. Yi JH, Cho Y, Hwang IK (1998) Fermentative characteristics of kimchi prepared by addition of different kinds of minor ingredients. Korean J Soc Food Sci, 14, 1-8 